\title{
Phenotypic and morphological characterizations of indigenous chicken populations in Kaffa Zone, South- Western Ethiopia
}

\author{
Tadele $\mathrm{A}^{1}$, Melesse $\mathrm{A}^{2 *}$ and Taye $\mathrm{M}^{\mathbf{2}}$ \\ ${ }^{1}$ Department of Animal Science, Mizan-Tepi, University, Ethiopia \\ ${ }^{2}$ School of Animal and Range Sciences, Hawassa University, Ethiopia
}

\begin{abstract}
The main objective of this study was to characterize the qualitative and quantitative morphometric traits of indigenous chicken populations reared in Kaffa Zone, South-Western Ethiopia. From the ten districts of Kaffa Zone, three districts were purposively selected based on their potential for chicken population. Data on both qualitative and quantitative traits of the indigenous chicken populations were collected from 300 randomly selected households of the three districts. Visual appraisals, body weight and linear body measurements were taken from 900 adult indigenous chickens of both sexes in the selected households. The results indicated that the average chicken flock size, clutch size and annual egg number per hen per year were $8.68,3.6$ and 44 , respectively. The predominant comb type for males were single (59.7\%) followed by rose comb (37\%) while72.2 \% of females were single combed followed by rose combs (24\%). In males, red plumage color (57.3\%), yellow shank color $(61 \%)$, red earlobe color $(80.7 \%)$ and yellow skin color $(56 \%)$ were the dominant phenotypic traits. However, female chickens were characterized by reddish brown plumage color (35.8\%), white shank color (33.3\%), white earlobe color (44.2\%) and white skin color (75\%). The overall mean values of body weight, body length, wingspan, back length, keel bone length, chest width, shank length, and shank circumference were $1.31 \mathrm{~kg}, 38.6 \mathrm{~cm}, 38.8 \mathrm{~cm}, 18.4 \mathrm{~cm}, 10.3 \mathrm{~cm}, 26.1 \mathrm{~cm}$, $7.49 \mathrm{~cm}$ and $3.59 \mathrm{~cm}$, respectively. The values of all linear body measurement traits were significantly differed $(\mathrm{P}<0.01)$ across the study districts. The best predictor for assessing the body weight of male chickens was chest width, shank length and wing span, whereas chest width, shank circumference and keel bone length were best for females. The hierarchical cluster analysis showed the presence of phenotypic variability among the chicken populations reared in the study areas. The present finding suggests that indigenous chickens in the study area possess unique genetic potentials that would be used for further breeding programs for optimum utilization of these genetic resources by the rural communities.
\end{abstract}

\section{Introduction}

Animal production in general and chicken rearing in particular plays a vital socio-economic role for people living in low-income countries like Ethiopia. In Ethiopia, chickens are the most widespread and almost every rural family owns them. They provide a valuable source of family protein and income [1,2,3]. Currently the total chicken population in Ethiopia is about 56.9 million, of which $95.9 \%$ are indigenous chickens, which are mainly kept by smallholder rural farmers in scavenging system (CSA, 2015) [4]. The remaining 2.79 and 1.35 percent are hybrid and exotic chickens, respectively.

Indigenous chickens are predominantly kept by the rural society and have large variations in body conformation, plumage color and comb type $[1,5]$. The variations in morphological traits such as feather type, shank color, ear-lobe color, and comb types are common among indigenous chicken populations. However, the indigenous chickens that have mainly been selected naturally or by the farmers who keep them for their adaptive fitness to specific area are often poor in their egg production and characterized by late maturation as well as long broodiness $[6,7]$. Due to their low genetic potentials, prevalence of diseases and predators, limited feed resources, constraints related to institutional, socio-economic, and infrastructural practices, the economic contribution of indigenous chicken is not proportional to their huge number.

On the other hand, the indigenous chickens are good scavengers and foragers, well adapted to harsh environmental conditions and their minimal space requirements make chicken rearing a suitable activity and an alternative income source for the rural Ethiopian farmers. In addition, the local chicken sector has been playing a significant role in poverty alleviation, food security and economic empowerments for vulnerable groups, women and children $[7,8]$.

The increased global use of highly productive breeds leads to a loss of genetic diversity in most species of farm animals. As a result, highly productive breeds have continuously replaced indigenous breeds. In Ethiopia, the introduction of exotic chicken breeds to the local environment has led huge threat and pressure to the indigenous chicken populations. Consequently, the genetic merits of indigenous chicken populations have been diluted with exotic breeds $[9,10]$.

Hence, conservation is an important step, as it is a way for maintaining the existing local chicken populations that have been adapted to the local environment [9]. Thus, characterization provides data on present and potential future uses of those indigenous chicken

Correspondence to: Aberra Melesse, School of Animal and Range Sciences, Hawassa University, Ethiopia, E-mail: a_melesse@uni-hohenheim.de, a_ melesse@yahoo.com

Key words: Kaffa zone; indigenous chicken; phenotypic characterization; qualitative traits; quantitative traits; kebeles

Received: March 02, 2018; Accepted: March 22, 2018; Published: March 27, 2018 
populations and establishes their current state as distinct breed populations and their risk status.

In Ethiopia, the major challenge in the improvement of chicken is lack of adequate information on the genetic potentials of the available indigenous chicken populations. Knowledge and understanding of the chicken production system, unique characteristics, opportunities and constraints are crucial in designing and implementation of indigenous chicken-based development programs, which can beneficial to the smallholder rural societies $[10,11]$. Therefore, the present study was conducted to characterize and describe the production potentials, qualitative and quantitative traits of indigenous chicken populations reared in three districts of Kaffa Zone, South-Western Ethiopia.

\section{Materials and methods}

\section{Description of the study area}

This study was conducted in Kaffa Zone, which is located between $60^{\circ}, 24^{\prime}-8^{\circ}, 13^{\prime}$ North latitude and $35^{\circ}, 30^{\prime}-36^{\circ}, 46^{\prime}$ East longitude in Southe Western part of Ethiopia. The Kaffa Zone is divided into ten districts and has three conventional agro-climatic zones based on variations in altitude and temperature. These are the highland (2500 - $3000 \mathrm{~m}$ a.s.l), midland (1500 - $2500 \mathrm{~m}$ a.s.l) and lowland (500 - 1500 $\mathrm{m}$ a.s.l), which cover $11.6 \%, 59.5 \%$ and $28.9 \%$, respectively of the total area. The mean annual temperature of the area ranges $10.1^{\circ} \mathrm{C}-27.5^{\circ} \mathrm{C}$. The warmest months are February, March and April while the coldest months are July and August. The Kaffa Zone receives the highest amount of annual rainfall in the region, which ranges from 1001-2200 mm.

\section{Sampling technique and methods of data collection}

The study districts were purposively selected based on their potential for chicken production, accessibility and presence of indigenous chicken productions. From ten districts of Kaffa Zone, three districts namely Decha, Chena and Gimbo districts were selected from which 15 rural kebeles (seven from Decha; four from each Chena and Gimbo district) were randomly sampled. Then, 20 households from each rural kebeles (totaling 300) that possess a minimum of five matured indigenous chickens were randomly selected. Closely adjacent households were also skipped to avoid the risk of sampling chickens sharing the same cock. From each household, three matured chickens ( 1 male and 2 female) were sampled for the measurement of qualitative and quantitative traits. Accordingly, a total number of 900 indigenous chickens of both sexes whose age was seven months and above were randomly sampled from each household. This age was chosen by considering slow maturation rate of indigenous chickens to attain adult stage and was determined by "recalling methods" of the interviewed farmers. A semi-structured questionnaire was also used to collect data on production systems, qualitative and quantitative traits of indigenous chickens.

\section{Measurements of quantitative and qualitative traits}

Quantitative measurements of linear traits and body weight were taken on sampled indigenous chickens of both sexes using a textile measuring tape $(\mathrm{cm})$ and a hanging spring balance $(\mathrm{kg})$. Data on body weight, chest width (CW), body length (BL), shank length (SHL) and circumference $(\mathrm{SHC})$, keel bone length $(\mathrm{KBL})$, back length $(\mathrm{BkL})$ and wing span (WS) were taken from both sexes following FAO's descriptor for the characterization of chicken genetic resources [12].

Qualitative phenotypic traits such as feather morphology, feather distribution, plumage color, skin color, shank color, ear-lobe color, comb type and head shape were also observed following FAO descriptors for chicken genetic resources [12].

\section{Estimating the effective population size and inbreeding rate}

Data on effective population size was collected from the surveyed chicken populations. Effective population size for a randomly mated population was then calculated according to Falconer and Mackay (1996) by using the following equation:

$$
\mathrm{Ne}=\frac{4(\mathrm{Nm} \times \mathrm{Nf})}{\mathrm{Nm}+\mathrm{Nf}}
$$

$\mathrm{Ne}=$ effective population size; $\mathrm{Nm}=$ number of breeding males; $\mathrm{Nf}$ $=$ number of breeding females

Rate of inbreeding $(\Delta \mathrm{F})$ of the chicken populations was estimated from the effective population size $(\mathrm{Ne})$ according to the methods of Falconer and Mackay (1996) and Maiwashe et al. (2006).

\section{Statistical analysis}

Data collected on qualitative and quantitative traits of indigenous chicken populations were coded and entered into a computer using Microsoft Office Excel 2007. Body weight and linear body measurement traits were analyzed using the General Linear Model (GLM) procedures of Statistical Analysis System (2002, ver. 8.2; SAS Inst. Inc., Cary, NC). The model was fitted to main effects of district and sex on body weight and linear body measurements of chickens. Distinct measurements on the qualitative morphological traits were analyzed using frequency procedure of Chi-square $\left(\chi^{2}\right)$ test. Sampling districts were fitted as fixed independent variables. Means were compared using Duncan's multiple range test and values were considered significant at $P<0.05$. Stepwise multiple regression procedure was also used to regress body weight for both sexes to determine the best-fitting regression equations for the prediction of live body weight. In addition, hierarchical cluster analysis was used to analyze the quantitative traits of indigenous chicken populations using SPSS (SPSS 2007, ver. 16.0).

The following models were used for the statistical analysis:

Model 1: Yijk $=\mu+A i+S j+e i j k$

Where:

Yijk = The observed linear body measurements of $\mathrm{k}^{\text {th }}$ individual chicken

$\mu=$ overall mean

$A i=$ fixed effect of $i^{\text {th }}$ district $(i=1,2$ and 3$)$

$S j=$ fixed effect of $j^{\text {th }} \operatorname{sex}(1=$ male; $2=$ female $)$

eijk $=$ random error

Model 2: $Y j=\beta_{0}+\beta_{1} X_{1}+\beta_{2} X_{2}+\beta_{3} X_{3}+\beta_{4} X_{4}+\beta_{5} X_{5}+\beta_{6} X_{6}+\beta_{7} X_{7}+e_{i j}$ Where:

$\mathrm{Yj}=$ Response variable or predicted mean body weight of chickens $\beta_{0}=$ the intercept

$\mathrm{X}_{1}+\mathrm{X}_{2}+\mathrm{X}_{3}+\mathrm{X}_{4}+\mathrm{X}_{5}+\mathrm{X}_{6}$ and $\mathrm{X}_{7}$ are the explanatory variables for body length, chest width, keel bone length; shank length and circumference, back length and wing span, respectively

$\beta_{1}+\beta_{2}+\beta_{3}+\beta_{4}+\beta_{5}+\beta_{6}$ and $\beta_{7}$ are the regression coefficient of the variables $\mathrm{X}_{1}+\mathrm{X}_{2}+\mathrm{X}_{3}+\mathrm{X}_{4}+\mathrm{X}_{5}+\mathrm{X}_{6}$ and $\mathrm{X}_{7}$

$e_{i j}=$ the residual error 


\section{Results}

\section{Flock size and production potentials of indigenous chickens}

As shown in Table 1, the average flock size per household in Decha, Chena and Gimbo districts was 9.02, 8.83 and 8.01, respectively with an overall mean of 8.68 . The largest proportions of chicken populations were reported from Decha and Chena districts which were $(\mathrm{p}<0.05)$ higher than those found in Gimbo district.

The egg number per hen per clutch in the present study was 12.3 , 12.2 and 12.6 in Decha, Chena and Gimbo districts, respectively (Table 1). Average number of days per clutch (clutch length) was lower in Gimbo district than in Decha and Chena districts. In general, the average egg and clutch number per hen per year in the current study was 44 and 3.6, respectively. The hatchability of chicks form incubated eggs was $(\mathrm{p}<0.05)$ lower in Gimbo district than those of Decha.

\section{Qualitative traits}

Comb type: As shown in Table 2, the dominant comb type in the study area was single comb in both sexes, although the proportion was higher in female than male. Rose comb was the second largest comb type observed in both sexes across all the study districts. Although the occurrence of comb type across the study districts were comparable, significance differences $(P<0.01)$ between male and female chickens were observed.

Head shape: The present investigations revealed that, significantly higher differences were observed in head shape between male and female $(P<0.01)$ chickens and among the studied districts $(P<0.05)$. More than three fourth $(92 \%)$ of male and $(78.3 \%)$ female chicken in the study districts had snakehead shape and significance differences were observed among the districts.

Shank color: The color of shank in males was predominantly yellow with 69.3, 55 and $52.5 \%$ in Decha, Chena and Gimbo districts, respectively. In female chickens, however, white shank color was found to be the dominant with the proportion of 33.2 and $40.6 \%$ in Decha and Chena districts, respectively. Females in Gimbo districts were characterized by yellow shank color followed by white and black. Grey-blue and green shank color was also observed across the study districts in low proportions (Table 2). The observed shank color, were significantly different $(\mathrm{P}<0.01)$ among the studied districts in between male and female chickens.

Earlobe color: As presented in Table 2, there were highly significance $(\mathrm{P}<0.01)$ differences in ear lobe color of chickens in the study district in both male and female chickens. Males with red earlobe

Table 1. Flock size and performance of indigenous chickens reared in three districts of Kaffa Zone, South Western Ethiopia (mean \pm SD)

\begin{tabular}{|c|c|c|c|}
\hline Parameters & Decha & Chena & Overall mean \\
\hline Average flock size/household & $9.02 \pm 0.24^{\mathrm{a}}$ & $8.83 \pm 0.34^{\mathrm{a}}$ & $8.01 \pm 0.25^{\mathrm{b}}$ \\
\hline Egg number /hen/clutch & $12.3 \pm 1.43$ & $12.2 \pm 1.64$ & $12.6 \pm 2.07$ \\
\hline Clutch length/hen (days) & $21.0 \pm 5.1^{\mathrm{a}}$ & $21.0 \pm 5.7^{\mathrm{a}}$ & $19.0 \pm 5.86^{\mathrm{b}}$ \\
\hline Clutch number per hen/year & $3.60 \pm 0.2$ & $3.60 \pm 0.2$ & $3.65 \pm 0.21$ \\
\hline Total egg number per hen/year & $44 \pm 5.3^{\mathrm{ab}}$ & $43.4 \pm 5.7^{\mathrm{b}}$ & 3.28 \\
\hline Hatchability (\%) & $81.6 \pm 7.0^{\mathrm{a}}$ & $80.3 \pm 5.5^{\text {ab }}$ & $45.6 \pm 7.12^{\mathrm{a}}$ \\
\hline Survivability of chicks (\%) & $49.1 \pm 8.7$ & $48.8 \pm 10.0$ & $78.6 \pm 8.9^{\mathrm{b}}$ \\
\hline
\end{tabular}

a,b Row means with different superscript letters are significantly different $(\mathrm{P}<0.05)$; $\mathrm{SD}=$ standard deviation

Table 2. Absolute and percentage (in brackets) values of some qualitative traits of indigenous chicken populations reared in three districts of Kaffa Zone $(\mathrm{N}=900)$

\begin{tabular}{|c|c|c|c|c|c|c|c|c|c|c|}
\hline \multirow{2}{*}{ Qualitative traits } & \multicolumn{2}{|l|}{ Decha } & \multicolumn{2}{|l|}{ Chena } & \multicolumn{2}{|l|}{ Gimbo } & \multicolumn{2}{|c|}{ Overall (\%) } & \multicolumn{2}{|l|}{$\mathrm{X}^{2}$ - test } \\
\hline & Male & Female & Male & Female & Male & Female & Male & Female & District & Sex \\
\hline Comb type (\%) & & & & & & & & & $7.41^{\mathrm{ns}}$ & $14.9^{* * *}$ \\
\hline Rose & 53(37.9) & $75(26.8)$ & $28(35)$ & $28(17.5)$ & $30(37.5)$ & $46(28.7)$ & 37.0 & 24.0 & & \\
\hline Single & $82(58.6)$ & 201(71.8) & $47(58.7)$ & $128(80)$ & $50(62.5)$ & $104(65)$ & 59.7 & 72.2 & & \\
\hline Deformed rose & $5(3.5)$ & $4(1.40)$ & $5(6.30)$ & $4(2.50)$ & NR & $10(6.25)$ & 3.33 & 3 & & \\
\hline Head shape (\%) & & & & & & & & & $7.0^{*}$ & $26.3^{* * *}$ \\
\hline Snake & $129(92.1)$ & $209(74.6)$ & 79(98.7) & 133(83.1) & $68(85)$ & $128(80)$ & 92 & 78.3 & & \\
\hline Plain & $11(7.9)$ & $71(25.4)$ & $1(1.30)$ & $27(16.9)$ & $12(15)$ & $32(20)$ & 8 & 21.7 & & \\
\hline Shank color (\%) & & & & & & & & & $53.6^{* *}$ & $85.6^{* *}$ \\
\hline Yellow & $97(69.3)$ & $87(31.1)$ & $44(55)$ & $41(25.6)$ & $42(52.5)$ & $64(40)$ & 61 & 32.0 & & \\
\hline Black & $9(6.4)$ & $91(32.5)$ & $5(6.25)$ & $27(16.9)$ & $4(5.00)$ & $30(18.7)$ & 6 & 24.7 & & \\
\hline White & $33(23.6)$ & $93(33.2)$ & $22(27.5)$ & $65(40.6)$ & $28(35)$ & $42(26.3)$ & 27.7 & 33.3 & & \\
\hline Grey blue & $1(0.7)$ & $3(1.1)$ & $5(6.25)$ & $12(7.50)$ & $2(2.50)$ & $10(6.25)$ & 2.67 & 4.17 & & \\
\hline Green & NR & $6(2.1)$ & $4(5.00)$ & $15(9.38)$ & $4(5.00)$ & $14(8.75)$ & 2.67 & 5.83 & & \\
\hline Earlobe color $(\%)$ & & & & & & & & & $47.2^{* * *}$ & $301^{* *}$ \\
\hline White & $11(7.86)$ & $143(51.1)$ & $6(7.50)$ & $60(37.5)$ & $6(7.50)$ & $62(38.8)$ & 7.67 & 44.2 & & \\
\hline Red & $116(82.8)$ & $64(22.8)$ & $66(82.5)$ & $38(23.7)$ & $60(75)$ & $24(15)$ & 80.7 & 21 & & \\
\hline Yellow & NR & NR & $2(2.50)$ & $18(11.3)$ & $2(2.50)$ & $6(3.75)$ & 1.33 & 4.5 & & \\
\hline Red-white & 13(9.29) & $56(20)$ & $6(7.50)$ & $37(23.1)$ & $12(15)$ & $54(33.7)$ & 10.3 & 24.5 & & \\
\hline Gray & NR & $14(5.00)$ & NR & $7(4.38)$ & NR & $14(8.75)$ & NR & 5.83 & & \\
\hline Skin color $(\%)$ & & & & & & & & & $60.6^{* *}$ & $181.5^{* * *}$ \\
\hline White & $57(40.7)$ & $219(78.2)$ & $30(37.5)$ & 113(70.6) & $22(27.5)$ & $118(73.7)$ & 36.3 & 75 & & \\
\hline Pink & $7(5.00)$ & $26(9.29)$ & $10(12.5)$ & $34(21.3)$ & $6(7.50)$ & $8(5.00)$ & 7.67 & 11.3 & & \\
\hline Yellow & $76(54.3)$ & $35(12.5)$ & $40(50)$ & $13(8.13)$ & $52(65)$ & $34(21.3)$ & 56 & 13.7 & & \\
\hline
\end{tabular}

${ }^{*} \mathrm{p}<0.05 ; * * \mathrm{p}<0.01 ; \mathrm{ns}=$ non significant; $\mathrm{X}^{2}$ - test $=\mathrm{Chi}-$ square test $\mathrm{N}=$ number of sampled chicken; $\mathrm{NR}=$ not reported 
color were dominant in the studied districts. Females, however, had predominantly white earlobe color followed by red-white. On the other hand, yellow earlobe colours were observed in Chena and Gimbo districts with minimum proportions.

Skin color: There was a $(\mathrm{P}<0.01)$ higher difference in skin color across the study districts for both male and female chickens. Accordingly, yellow was reported as the predominant skin color in males with the proportion of 54.3, 50 and $65 \%$ in Decha, Chena and Gimbo districts, respectively. In females, white was the prominent skin color observed across all studied districts. In addition, pink skin color was also recorded across all the investigated districts with low proportions.

\section{Description of feather morphology, distribution and plumage colours}

Feather morphology and distribution: Variations in feather morphology, distribution, and plumage color characteristics of the investigated indigenous chickens are presented in Table 3 . The present finding revealed that there is higher $(\mathrm{P}<0.01)$ difference in feather distribution across the study districts in both sexes. Accordingly, male chickens in Decha, Chena and Gimbo districts had normal feathered with the proportion of $87.9,92.5$ and $82.5 \%$, respectively. Females were also characterized by normal feather with proportions of 71.1, 78.8 and
78.7 \% in Decha, Chena and Gimbo districts, respectively. Feather morphology of the studied chicken populations was normal across all the studied districts in both male and female chickens.

Plumage color: Red was the predominant plumage color of males across all the studied districts accounting for 59.3, 53.8 and $57.5 \%$, in Decha, Chana and Gimbo districts, respectively. Grayish plumage color was also the second prominent color in males. Black, white, yellowish brown, multi-color color patterns were also observed in the studied districts with low proportions. Females reared in all districts were predominantly characterized by reddish brown plumage. Black, black with white tips, white with red tips, white, black and white mixtures, red plumage colours were also the other feather colours observed in the studied districts.

\section{Quantitative morphological traits}

As shown in Table 4, district had significant effect on all quantitative traits except for body weight where as sex had significant effect on all quantitative traits. The overall average body weight of males and females was $1.49 \mathrm{~kg}$ and $1.21 \mathrm{~kg}$, respectively. The results for keel bone and wing span, body length and width, shank length and circumference were highly different across all the studied districts. The value of keel bone for chickens reared in Gimbo district was significantly higher $(P<0.01)$ than, Decha and Chena districts. However, there was no

Table 3. Variations in feather morphology, feather distribution and plumage color of indigenous chicken populations in three districts of Kaffa Zone, South Western Ethiopia ( $\mathrm{N}=900$ )

\begin{tabular}{|c|c|c|c|c|c|c|c|c|c|c|}
\hline \multirow{2}{*}{ Qualitative traits Feather characteristics } & \multicolumn{2}{|l|}{ Decha } & \multicolumn{2}{|l|}{ Chena } & \multicolumn{2}{|l|}{ Gimbo } & \multicolumn{2}{|c|}{ Overall (\%) } & \multicolumn{2}{|l|}{$\mathrm{X}^{2-}$ test } \\
\hline & Male & Female & Male & Female & Male & Female & Male & Female & District & Sex \\
\hline Feather morphology (\%) & & & & & & & & & ns & ns \\
\hline Normal & $140(100)$ & $280(100)$ & $80(100)$ & $160(100)$ & $80(100)$ & $160(100)$ & 100 & 100 & & \\
\hline Feather distribution (\%) & & & & & & & & & $21.5^{* *}$ & $25.2^{* *}$ \\
\hline Normal & 123(87.9) & 199(71.1) & $74(92.5)$ & $126(78.8)$ & $66(82.5)$ & $126(78.7)$ & 87.7 & 75.2 & & \\
\hline Naked neck & $4(2.86)$ & $8(2.86)$ & $5(6.25)$ & $9(5.63)$ & NR & $2(1.25)$ & 3 & 3.17 & & \\
\hline Plain & 11(7.86) & $71(25.4)$ & $1(1.25)$ & $25(15.6)$ & $12(15)$ & $30(18.7)$ & 8 & 21 & & \\
\hline Feathered shanks & $2(1.43)$ & $2(0.71)$ & NR & NR & $2(2.50)$ & $2(1.25)$ & 1.33 & 0.67 & & \\
\hline Plumage colors (\%) & & & & & & & & & $68.4^{* *}$ & $379^{* *}$ \\
\hline White (Netch) & $3(2.14)$ & $22(7.86)$ & $6(7.50)$ & $10(6.25)$ & NR & $8(5)$ & 3 & 6.67 & & \\
\hline Black (Tikur) & $10(7.14)$ & $46(16.4)$ & $7(8.75)$ & $42(26.3)$ & $10(12.5)$ & $24(15)$ & 9 & 15.2 & & \\
\hline Red (Kei) & $83(59.3)$ & $37(13.2)$ & $43(53.8)$ & 21(13.1) & $46(57.5)$ & $10(6.25)$ & 57.3 & 14.8 & & \\
\hline Grayish (Gebsima) & $27(19.3)$ & NR & $15(18.7)$ & $1(0.63)$ & $10(12.5)$ & $8(5)$ & 17.3 & 1.5 & & \\
\hline Black with white tips (Tikur teterima) & $8(5.71)$ & $46(16.4)$ & $2(2.50)$ & 18(11.3) & $2(2.50)$ & $32(20)$ & 4.0 & 16 & & \\
\hline Reddish brown (Kokima) & NR & 113(40.4) & NR & $50(31.3)$ & NR & $52(32.5)$ & NR & 35.8 & & \\
\hline Red with white tips (Kei teterima) & NR & $6(2.14)$ & $3(3.75)$ & $9(5.63)$ & NR & NR & 1.67 & 2.50 & & \\
\hline Yellowish brown (Wosera) & NR & $3(1.07)$ & $2(2.50)$ & $3(1.88)$ & $2(2.50)$ & $20(12.5)$ & 2.0 & 4.33 & & \\
\hline Black and white mixtures (Amorima) & NR & $7(2.50)$ & NR & $4(2.50)$ & $4(5.00)$ & $6(3.75)$ & NR & 2.83 & & \\
\hline Multicolor (Ambesima) & $9(6.43)$ & NR & $2(2.50)$ & $2(1.25)$ & $6(7.50)$ & NR & 5.67 & 0.33 & & \\
\hline
\end{tabular}

$\mathrm{X}^{2}=$ chi-square; $* \mathrm{p}<0.05 ; * * \mathrm{p}<0.01 ; \mathrm{ns}=$ non significant; $\mathrm{NR}=$ not reported; $\mathrm{N}=$ number of sampled chicken; Numbers in parentheses are percentage values; Names in parenthesis are in Amharic, the federal official working language of Ethiopia

Table 4. Average body weight $(\mathrm{kg} \pm \mathrm{SE})$ and linear body measurement traits $(\mathrm{cm})$ of male and female indigenous chicken populations in three districts of Kaffa zone

\begin{tabular}{|c|c|c|c|c|c|c|c|c|c|}
\hline Items & $\mathrm{N}$ & BW & $\mathrm{BL}$ & $\mathrm{CW}$ & KBL & SHL & SHC & BKL & WS \\
\hline Overall & 900 & 1.31 & 38.6 & 26.1 & 10.3 & 7.49 & 3.59 & 18.4 & 38.8 \\
\hline $\mathrm{CV} \%$ & & 12.5 & 4.73 & 5.92 & 6.6 & 8.14 & 7.54 & 6.36 & 5.45 \\
\hline Districts & & ns & $* *$ & $* *$ & $* *$ & $* *$ & $* *$ & $*$ & $* *$ \\
\hline Chena & 240 & $1.36 \pm 0.01$ & $40.0 \pm 0.14^{\mathrm{a}}$ & $26.0 \pm 0.11^{\mathrm{b}}$ & $10.5 \pm 0.06^{\mathrm{b}}$ & $7.87 \pm 0.05^{\mathrm{a}}$ & $3.69 \pm 0.02^{\mathrm{b}}$ & $19.1 \pm 0.12^{\mathrm{a}}$ & $40.8 \pm 0.16^{\mathrm{a}}$ \\
\hline Decha & 420 & $1.35 \pm 0.01$ & $39.0 \pm 0.12^{b}$ & $26.7 \pm 0.1^{\mathrm{a}}$ & $10.4 \pm 0.04^{b}$ & $7.56 \pm 0.05^{\mathrm{b}}$ & $3.63 \pm 0.02^{\mathrm{c}}$ & $18.9 \pm 0.1^{\mathrm{ab}}$ & $39.3 \pm 0.14^{\mathrm{b}}$ \\
\hline Gimbo & 240 & $1.36 \pm 0.02$ & $38.5 \pm 0.18^{\mathrm{c}}$ & $26.5 \pm 0.14^{\mathrm{a}}$ & $10.6 \pm 0.06^{\mathrm{a}}$ & $7.89 \pm 0.06^{\mathrm{a}}$ & $3.78 \pm 0.03^{\mathrm{a}}$ & $18.8 \pm 0.13^{b}$ & $38.7 \pm 0.21^{\mathrm{c}}$ \\
\hline Sex & & $* *$ & $* *$ & $* *$ & $* *$ & $* *$ & $* *$ & $* *$ & $* *$ \\
\hline Male & 300 & $1.49 \pm 0.01^{\mathrm{a}}$ & $41 \pm 0.11^{\mathrm{a}}$ & $27.6 \pm 0.1^{\mathrm{a}}$ & $11.2 \pm 0.04^{\mathrm{a}}$ & $8.44 \pm 0.04^{\mathrm{a}}$ & $3.95 \pm 0.02^{\mathrm{a}}$ & $20.5 \pm 0.07^{\mathrm{a}}$ & $41.6 \pm 0.14^{\mathrm{a}}$ \\
\hline Female & 600 & $1.21 \pm 0.01^{b}$ & $37.4 \pm 0.08^{b}$ & $25.3 \pm 0.06^{\mathrm{b}}$ & $9.8 \pm 0.03^{b}$ & $7.02 \pm 0.03^{b}$ & $3.4 \pm 0.01^{\mathrm{b}}$ & $17.4 \pm 0.05^{\mathrm{b}}$ & $37.5 \pm 0.1^{\mathrm{b}}$ \\
\hline
\end{tabular}

a, b,c, Means between columns within each independent variables bearing different superscript letters are significant $(\mathrm{P}<0.05) ;(\mathrm{P}<0.05) ; * *(\mathrm{p}<0.01) ; \mathrm{ns}=$ non-significance; $\mathrm{SE}=\mathrm{Standard}$ error of the mean; $\mathrm{BW}=$ live body weight; $\mathrm{BL}=$ body length; $\mathrm{CW}=$ Chest width; $\mathrm{KBL}=$ keel bone length; $\mathrm{SHL}=$ shank length; $\mathrm{SHC}=$ shank circumference; $\mathrm{BKL}=$ back length; $\mathrm{WS}=$ wing span 
significance difference $(P>0.05)$ in keel bone of chickens reared in Decha and Chena districts.

Wing span and body length of chickens reared in the study districts were significantly $(P<0.01)$ different. Wing span and body length in Chena chickens had higher value than Decha and Gimbo districts. Wing span and body length of chickens reared in Decha were also higher than Gimbo districts. The value of back length of chickens reared in Chena was higher $(P<0.05)$ than Gimbo districts while comparable values were observed in those of Decha and Gimbo districts. The value of chest width in chickens reared in Chena district was lower $(P<$ 0.01) than those chickens reared in Decha and Gimbo districts while Decha and Gimbo districts had comparable value. Shank length values of chickens measured in Chena and Gimbo district did not differ, but were $(P<0.01)$ higher than those observed in Decha district. The shank circumference of chickens reared in all study districts differed significantly $(P<0.01)$ being higher in Gimbo district than those reared Chena and Decha districts. Chickens reared in Chena district had higher shank circumference value than those of Decha district.

\section{Body weight to shank length ratio}

In the present study, the ratio values of body weight to shank length in male chickens reared across the three districts were comparable. However, female chickens in Decha district had significantly higher $(P$ $<0.01)$ ratio values than the other districts.

\section{Keel bone length to chest width ratio}

The result relating to keel bone length to chest width ratio values (Table 5), indicates male chickens reared in Chena district had significantly higher $(P<0.01)$ value than the other chicken populations. On the other hand, female chickens in Decha district had significantly lower value than the other chicken populations.

\section{Cluster analysis}

The hierarchical cluster analysis was employed to distinguish the distribution of indigenous chicken populations based on their quantitative morphological trait in the study area. Based on this, two clusters were found having most of the chicken populations which were grouped under cluster 1. In addition, some chickens reared in the studied rural kebeles were also grouped under cluster 2, which was distributed more or less uniformly under same distance (Figure 1). The dendogram indicates that the majority of chickens in the study area showed close relationship among the studied rural kebeles. However, those chickens reared in the rural kebeles of Keikela (Gimbo district), Awurada Beha (Decha district) and Bobacocha (Chena district) were distantly related with the rest of chicken populations (Figure 1).

\section{Body weight prediction}

As presented in Table 6, all linear body measurements of chickens in the studied districts were highly correlated with body weight. Stepwise multiple regression analysis was carried out to describe the quantitative relationship between the response variable (body weight) and linear body measurement traits. Predictive equation relating to body weight of indigenous chickens to linear body measurements in the study area are shown in Table 7 . Body weight and linear body measurements showed strong $(P<0.01)$ associations. Comparatively males from Gimbo district had the best predictor for assessing body

Table 5. Live body weight /shank length and Keel bone length/chest width ratios of indigenous chicken populations reared in three districts of Kaffa Zone, South Western, Ethiopia (mean $\pm \mathrm{SD} ; \mathrm{N}=900$ )

\begin{tabular}{|l|l|l|l|l|l|l|l|}
\hline Phenotypic traits & Sex & CV\% & Decha $(\mathrm{n}=420)$ & Chena $(\mathrm{n}=240)$ & Gimbo $(\mathrm{n}=240)$ \\
\hline $\begin{array}{l}\text { Body weight/shank length ratio }(\mathrm{kg} / \\
\mathrm{cm})\end{array}$ & Male & 12.5 & $0.179 \pm 0.025$ & $0.177 \pm 0.015$ & $0.175 \pm 0.023$ \\
\cline { 2 - 6 } & Female & 15.2 & $0.178 \pm 0.031^{\mathrm{a}}$ & $0.169 \pm 0.019^{\mathrm{b}}$ & $0.168 \pm 0.023^{\mathrm{b}}$ \\
\hline $\begin{array}{l}\text { Keel bone length/chest width ratio } \\
(\mathrm{cm} / \mathrm{cm})\end{array}$ & Male & 5.81 & $0.398 \pm 0.022^{\mathrm{c}}$ & $0.416 \pm 0.022^{\mathrm{a}}$ & $0.406 \pm 0.027^{\mathrm{b}}$ & $0.178 \pm 0.022$ \\
\cline { 2 - 5 } & Female & 6.76 & $0.382 \pm 0.023^{\mathrm{b}}$ & $0.394 \pm 0.023^{\mathrm{a}}$ & $0.396 \pm 0.034^{\mathrm{a}}$ & $0.405 \pm 0.025$ \\
\hline
\end{tabular}

a,b,c Means across a raw with different superscript letters are significantly $(\mathrm{p}<0.01)$ different; $* *(\mathrm{p}<0.01)$; ns, non-significant.

Table 6. Association of body weight with linear body traits of indigenous male (upper diagonal, $\mathrm{N}=300$ ) and female (lower diagonal = 600) chicken populations of Kaffa Zone, South Western Ethiopia

\begin{tabular}{|c|c|c|c|c|c|c|c|c|}
\hline Linear body traits & Body weight & Body length & Chest width & Keel bone length & Shank length & $\begin{array}{c}\text { Shank } \\
\text { circumference }\end{array}$ & Back length & Wing span \\
\hline Body weight & & $0.335^{* *}$ & $0.425^{* *}$ & $0.360^{* *}$ & $0.276^{* *}$ & $0.348^{* *}$ & $0.453^{* *}$ & $0.369^{* *}$ \\
\hline Body length & $0.459^{* *}$ & & $0.383^{* * *}$ & $0.501^{* *}$ & $0.438^{* * *}$ & $0.325^{* *}$ & $0.553^{* *}$ & $0.730^{* *}$ \\
\hline Chest width & $0.447^{* *}$ & $0.246^{* *}$ & & $0.573^{* *}$ & $0.393^{* * *}$ & $0.410^{* *}$ & $0.561^{* *}$ & $0.369^{* *}$ \\
\hline Keel bone length & $0.476^{* *}$ & $0.389^{* *}$ & $0.374^{* *}$ & & $0.356^{* *}$ & $0.326^{* *}$ & $0.456^{* *}$ & $0.515^{* *}$ \\
\hline Shank length & $0.327^{* *}$ & $0.322^{* *}$ & $0.293^{* *}$ & $0.489^{* *}$ & & $0.596^{* *}$ & $0.430^{* *}$ & $0.392^{* *}$ \\
\hline Shank circumference & $0.385^{* *}$ & $0.269^{* * *}$ & $0.396^{* *}$ & $0.464^{* *}$ & $0.575^{* *}$ & & $0.322^{* *}$ & $0.269^{* *}$ \\
\hline Back length & $0.408^{* *}$ & $0.413^{* *}$ & $0.403^{* *}$ & $0.392^{* *}$ & $0.344^{* * *}$ & $0.325^{* *}$ & & $0.417^{* * *}$ \\
\hline Wing span & $0.371^{* *}$ & $0.772^{* *}$ & $0.139^{* *}$ & $0.426^{* *}$ & $0.359^{* *}$ & $0.301^{* *}$ & $0.313^{* *}$ & \\
\hline
\end{tabular}

$* * \mathrm{P}<0.01$

Table 7. Stepwise multiple regression equations for estimation of body weight of male and female chickens reared in three districts of Kaffa Zone, South Western Ethiopia

\begin{tabular}{|l|l|l|l|l|}
\hline Sex & Districts & $\mathrm{R}^{2}$ adj. & Fitted stepwise multiple regression equations \\
\hline Male & Decha & 0.303 & $\mathrm{Y}=-0.496+0.06(\mathrm{BKL})+0.276(\mathrm{SHC})-0.098(\mathrm{SHL})+0.045(\mathrm{KBL})$ \\
\hline & Chena & 0.377 & $\mathrm{Y}=-0.388+0.048(\mathrm{KBL})+0.033(\mathrm{BKL})+0.24(\mathrm{CW})$ \\
\hline & Gimbo & 0.433 & $\mathrm{Y}=-1.161+0.033(\mathrm{CW})+0.1(\mathrm{SHL})+0.022(\mathrm{WS})$ \\
\hline Female & Decha & 0.350 & $\mathrm{Y}=-0.848+0.031(\mathrm{CW})+0.065(\mathrm{KBL})+0.017(\mathrm{BL})$ \\
\hline & Chena & 0.433 & $\mathrm{Y}=-0.917+0.040(\mathrm{CW})+0.208(\mathrm{SHC})+0.045(\mathrm{KBL})$ \\
\hline & Gimbo & 0.421 & $\mathrm{Y}=-1.126+0.026(\mathrm{BL})+0.020(\mathrm{CW})+0.047(\mathrm{KBL})+0.023(\mathrm{BKL})$ \\
\hline$* *$ \\
\hline
\end{tabular}

** $\mathrm{P}<0.01$ = highly significant; $\mathrm{R}^{2}$ adj. = adjusted coefficient of determination

$\mathrm{Y}=$ predicted body weight; $\mathrm{BL}=$ body length; $\mathrm{CW}=$ Chest width; $\mathrm{KBL}=$ keel bone length; $\mathrm{SHL}=$ shank length; $\mathrm{SHC}=$ shank circumference; $\mathrm{BKL}=$ back length; $\mathrm{WS}=$ wing span 


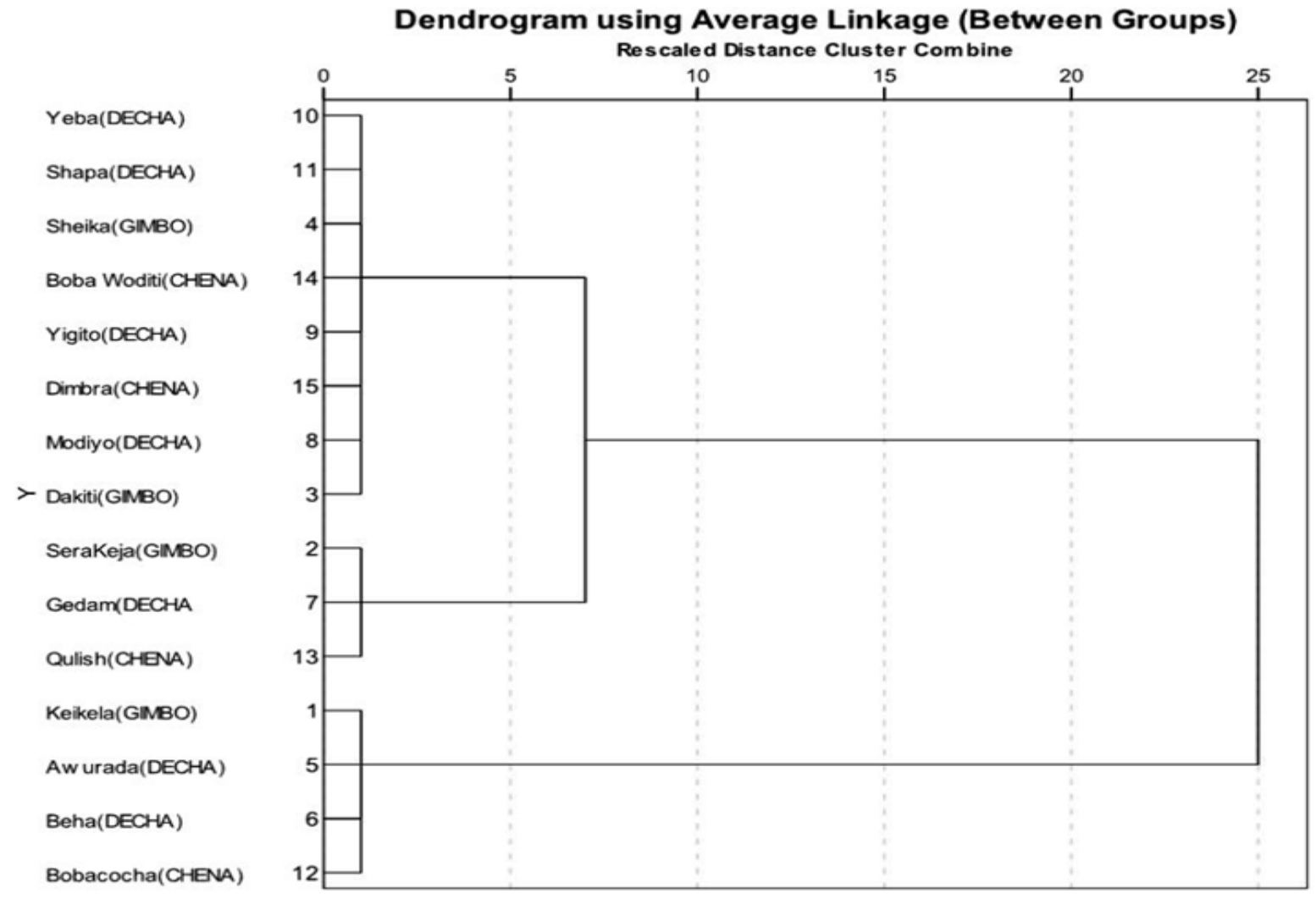

Figure 1. Dendogram showing the relationship among indigenous chicken populations

weight of chickens. However, in females, chickens in Chena district exhibited the best predictor for estimating body weight.

\section{Effective population size and rate of inbreeding}

The overall effective population size ( $\mathrm{Ne}$ ) was found to be 486 while the respective rate of inbreeding was $0.07,0.126$ and $0.13 \%$ in Decha, Chena and Gimbo districts with an overall $0.11 \%$ across the study areas (data not shown). In Decha district, the rate of inbreeding was comparatively lower than Chena and Gimbo districts. However, Chena and Gimbo districts had comparable rate of inbreeding values.

\section{Discussion}

\section{Flock ownership and productive performances}

The average chicken flock size (8.68) per household $(\mathrm{HH})$ in the current study is comparable with the reports of Nebiyu et al. (2013) who reported 8.5 chickens per $\mathrm{HH}$ in Allaba districts of Southern Ethiopia. The number of chickens per HH reported by [5] in Northwest Ethiopia (7.1), [13] in Southern region (7.9) as well as Mulgeta and Tebkew (2013) in Amhara region (7.76) are also in line with the findings of the present study. However, studies conducted in various parts of Ethiopia by some scholars [7] reported higher values while others [14] observed lower than the present study. These variations in flock size in different parts of the country might be due to the presence of seasonal outbreak of diseases, predators, feed resource availability, economic aspects of the community, environmental conditions and settlement pattern of the societies.

The average egg production per clutch per hen, number of eggs incubated, and hatchability of chicks was comparable with the reports of [4] and in close agreement with the findings of [15]. Highest value of eggs/clutch/hen was reported from Eastern Gojam Zone by Melkamu and Andarge (2013) and Mulgeta and Tebikew (2013) which was 17 eggs and 9-15eggs/clutch/hen, respectively. The average clutch number per hen per year and total egg number per hen per year in the current study was comparable with those of [15]. However, Melkamu and Andargie (2013) and Solomon et al. (2013) reported higher values of clutch number and egg number per hen per year. The management aspects of households in rearing their chickens might be the reason contributing for the observed variations in the production and reproduction traits of indigenous chickens in the country. The average hatchability of chickens in the current study is comparable with the results of [16] and [7]. However, observations by several scholars in various parts of the country were higher than the present study [16]. On the other hand, lower hatchability values were also reported from various parts of the country [11]. The average survival rate of chickens in the present study $(49.2 \%)$ was lower than most of the observations by $[7,11,16]$ with the respective values of 58.3, 52.3, 62.7 and $66.5 \%$. These variations in the productive performances of indigenous chickens might be due to seasonal outbreak of disease, predator attacks, poor nutrition, and poor management, availability of scavenging feed resources and feed supplements.

\section{Qualitative morphometrical traits}

In the present study, the observed qualitative morphometrical traits were in close agreement with the findings of $[7,10,17,11]$. The present study indicated that $59.7 \%$ of males and $72.2 \%$ of females were mainly characterized by single comb followed by rose comb, which is in line with the reports of [15]. Studies from other countries also indicated that, single comb was the dominant type over any other comb types 
[18-21]. Another study conducted in South-West and South parts of Ethiopia by [14] indicated that 59.2 and $31.8 \%$ of chickens were single and rose combed. However, the findings of [22] indicated that $48.4 \%$ of chickens in Horro district possessed rose combs. According to [5], the majority of chickens (50.7\%) in Northwest Ethiopia had possessed pea combs. The variation of comb type observed in different parts of the country and particularly in Ethiopia indicates existence of genetic variability among the indigenous chicken populations. The possession of single combs assists in heat dissipation by means of conduction and convection in tropical region where the ambient temperature is high [19]. The presence of several comb types observed in this study might be due the flow of genetic materials from one place to the other through marketing and other routes. Moreover, comb type is the result of interactions of various genes and comb size is associated with gonadal development and the intensity of light, either in natural or by artificial means [10].

In the current study, males (92\%) and females (78.3\%) had snakehead shape across all the study districts, which is in good agreement with the reports of $[11,14,23]$. The results of shank color in the present study indicated that male (61\%) and female (32\%) chickens possessed yellow shank, which was in line with the findings of $[7,10]$ who reported that majority of chicken populations (52.5\%) in southern and eastern parts of Ethiopia were characterized by yellow shank. Shank colors in chickens are mainly breed specific. Genes that affect the skin at different depths control it. The visible color is due to the combined effect of the different colors of the dermis and epidermis. So, the shank colors are a combination of the upper skin and deeper skin pigmentations. In modern poultry breeds, the yellow shank color is the dominant color followed by white and black. In some situations, shank colors may resemble the plumage color [24]. Nevertheless, the normal appearance of the shank color of scavenging chicken populations might be affected by the disease situations among which external parasites such as mites could considerably impede the normal expression of shank color (personal observations).

The results pertaining to earlobe color in the current study showed that the majority of males $(80.7 \%)$ were characterized by the presence of red earlobe, which is in line with the reports of [7]. However, it was not in agreement with the observations of [25] from western and eastern parts of Ethiopia. Earlobe color of domestic fowl is a breedspecific trait. The color of white ear lobe is due to the purine pigment, which is controlled by a number of genes. For instance, breeds of all Mediterranean chicken breeds (Leghorns) have 'white' ear lobes while other breeds red ear lobes. Red ear lobe is due to lack of genes that invoke the purine pigmentation [24]. In some situations, the white ear lobe can have a greenish or yellowish shade. Ear lobes, combs, and wattles have rich blood supply, which is essential for heat dissipation through the process of vasodilation.

In the present study, various plumage colors were observed among the indigenous chicken populations in the study area. The results of plumage colors varied between male and female chickens. In male chickens, red $(57.3 \%)$ and grayish (17.3\%) plumage colors were dominant while in females, yellowish brown (35.8\%), black with white tips (16\%), black (15.2\%) and red (14.8\%) were the most frequent plumage colors observed. These findings are comparable with those reported by $[10,11,23]$. [5] reported that the chickens in Northwestern Ethiopia were characterized by white $(25.5 \%)$ plumage color, which differs from the current findings. Moreover, local chickens from South West and South parts of Ethiopia exhibited brown plumage colors [14]. The occurrence of various plumage colors observed in the indigenous chicken populations of Ethiopia in general and particularly in this study area, might be due to the fact that, the preference of people towards red, white and brown plumages which accounted for the largest occurrence of these plumage colors across the country.

\section{Quantitative morphological traits}

The average values of live weight of males and females observed in the current study were comparable with the findings of various scholars in Ethiopia [7,10,26]. High live body weight of chickens for both sexes (1.63 kg male and $1.37 \mathrm{~kg}$ female) was reported for chickens reared in North Gonder Zone of Ethiopia [23]. The variation of live weight of males and females in the present study agrees with the reports of various scholars in the country $[7,26]$. Sexual dimorphism in indigenous chicken populations has been reported by $[7,10,26]$ which agrees with the present study. The observed sexual dimorphism in the current study and elsewhere might be because males and female chickens do vary in growth rate as a result of hormonal actions.

The results on linear body measurement traits in the current study were comparable with most of the observations in different parts of the country. Accordingly, the average value of BL in the present study was in close agreement with the reports of $[11,22,23]$. However, it was higher than those of reported by $[7,14]$. These variations in body length might be due to the age of animals, ago-climatic conditions, and status of nutrition of chickens when various scholars collected the data.

The average value of $\mathrm{CW}$ in the current study was in close agreement with the reports of $[7,22]$. The $\mathrm{CW}$ is an indicator of fleshing of a chicken. The average value of KBL in the present study was also comparable with the reports of [7,11]. However, [22] reported higher values of KBL from Horro and Jarso districts of Oromia Zone. These variations might be duet to age and type of local chicken breeds investigated at various locations. Length of keel and shank have been also regarded as good indicators of skeletal development of a bird, which is related to the amount of meat a chicken can carry [24]. The results obtained for average SHL in the present study were comparable with the reports of $[5,15,22]$. However, it was higher than those of reported by [7] in chickens reared in Southeastern Oromia Regional State of Ethiopia. The existence of such variations might be explained by the availability of scavengable feed resources both in quality and quantity in those different study locations.

The shank length and keel length to chest width ratios in the present study was relatively higher than those reported for Southern region of Ethiopia [10]. The body shank length and keel length to chest width ratios in chickens reflects the degree of fleshing in relation to body size and where it is normally higher with heavier body size [27]. Hence, the present study suggests chicken populations could be a viable option for meat production under scavenging feed management systems due to their relatively higher body shank length and keel length to chest width ratios.

The present average result pertaining to shank circumference was in close agreement with the reports of different scholars in Ethiopia $[7,15,23]$. The findings reported by [5] were, however, lower than the current study which may suggest that local chicken in the present study area might be suitable for meat production rather than for egg. The average values relating to back length were comparable with those reported by $[11,22]$ in Horro and Jarso districts of East Oromia Zone and Southwest Ethiopia, respectively. The average wing span obtained from the current study was comparable with the reports of [23]. Higher values of wing span were also reported by $[11,22]$. However, the wing 
span values of the current study were higher than those of reported by [7]. The observed significant effects of age on body weight and linear body measurement traits of chickens in the present study was in line with the reports of Semakula et al. (2011) and Ojedapo et al. (2012) who noted that, body weight and linear body measurements increases with the advancing age of chickens.

\section{Prediction of live body weight}

In the current study, positive and significant $(P<0.01)$ correlations was observed between body weight and linear body measurement traits and are in good agreement with the reports of [7,23]. These positive correlations of body weight with linear body measurements observed in the present study suggest that measuring one of these quantitative traits enables to predict the body weight of local chickens in rural farming society. The results of the present study and findings of other scholars therefore suggests that, selection for any of these linear body measurable traits will cause direct improvement in body weight of indigenous chicken populations $[7,20,28]$.

In the present study, the adjusted $\mathrm{R}^{2}$ values ranged from low (0.303) to relatively high (0.433) indicating that the calculated equations could be used to predict the body weight of chickens. Predictive equations provide a readily available tool in body weight estimation. This is particularly true in rural areas or areas where weighing scales are not available as suggested by $[7,21,23,29]$.

The use of hierarchical cluster analysis was effective in differentiating the indigenous chicken populations based on quantitative morphological traits. The formation of two groups of clusters seen in Figure 2 could correspond to correlations that exist among chicken populations. However, the result showed some of the chickens reared in some kebeles were distantly associated with rest of chickens. This implies the existence of phenotypic variation of chicken populations in the study area which is in agreement with the findings of [30-33] who noted that, phenotypic variability could be the main distinguishing characteristics of indigenous chicken populations throughout the world.

\section{Conclusion}

The predominant comb type observed in the current study was single comb in both male and female chickens followed by rose comb. In male chickens, red plumage, yellow shank, red earlobe and yellow skin colors were the main distinguishing features. However, females were predominantly characterized by reddish brown plumage, white shank, white skin and white ear-lobe colors across the study districts. Variations in linear body measurement traits were observed indicating the existence of genetic differences in major performance traits, which makes selection between local populations a viable option to improve the genetic potentials of local chicken populations. We recommend an in-depth molecular assessment to validate the level of genetic variations and relationship existing among indigenous chicken populations of the studied districts.

\section{Acknowledgement}

The authors acknowledge the Ministry of Agriculture and Natural resource, Mizan Agricultural, Technical, Vocational and Educational Training College for providing the financial support during the research work. We further express our gratitude for Kaffa Zone, Decha, Gimbo and Chena district Livestock and Fishery Resource Offices for their cooperation during the process of data collection. We are very much grateful those households and development agents who actively participated in this study by devoting their time.

\section{References}

1. Moges F, Melesse A, Dessie T (2009) Assessment of the prevailing handling, transportation, marketing and quality of eggs collected from scavenging hens in Bure district, North-West Ethiopia. Ethiopian J Anim Prod 9: 209-227.

2. Alewi M, Melesse A (2013) Evaluating the growth performance of local Kei chickens and their F1-Crosses with Rhode Island Red and Fayoumi breeds in watershed areas of Guraghe Administrative Zone, Southern Ethiopia. Trop Subtrop Agro-ecosyst 16: $39-50$.

3. Melesse A (2014) Significance of scavenging chicken production in the rural community of Africa for enhanced food security. World's Poult Sci J 70: 593-606.

4. CSA (2015) Central Statistical Agency, Agricultural Sample Survey Statistical Bulletin Addis Ababa, Ethiopia 188.

5. Halima H, Neser FW, van Marle-Koster E, de Kock A (2007) Phenotypic variation of indigenous chicken populations in northwest Ethiopia. Trop Anim Health Prod 39: 507-513. [Crossref]

6. Moges F, Melesse A, Dessie T (2010) Assessment of village chicken production system and evaluation of the productive and reproductive performance of local chicken ecotype in Bure district, North West Ethiopia. Afr J Agric Res 5:1739-1748.

7. Negassa D, Aberra Melesse A, Banerjee S (2014) Phenotypic characterization of indigenous chicken populations in Southeastern Oromia Regional State of Ethiopia. Anim Genetic Resources Info J 55: 101-113.

8. Moreki JC, Dikeme R, Poroga B (2010) The role of village poultry in food security and HIV/AIDS mitigation in Chobe District of Botswana. Livestock Research for Rural Development.

9. Woelders H, Zuidberg CA, Hiemstra SJ (2006) Animal Genetic Resources Conservation in the Netherlands and Europe: poultry perspective. Poult Sci 85:216-222. [Crossref]

10. Melesse, Negesse T (2011) Phenotypic and morphological characterization of indigenous chicken populations in Southern region of Ethiopia. Anim Genetic Resources Info J 49:19-31.

11. Bekele G, Kebede K, Ameha N (2015) On-farm Phenotypic Characterization of Indigenous Chicken and their Production System in Bench Maji Zone, South Western Ethiopia. Sci Technol Arts Res J 4: 68-73.

12. FAO (2012) Phenotypic characterization of animal genetic resources. Food and Agriculture Organization, Animal Production and Health Guidelines, No. 11. Rome.

13. Melesse A, Maak S, Schmidt R, von Lengerken G (2013) Effect of long-term heat stress on some performance traits and plasma enzyme activities in Naked-neck chickens and their F1 crosses with commercial layer breeds. Livest Sci 141: 227-231.

14. Moreda E, Singh H, Sisaye T, Johansson AM (2014) Phenotypic Characterization of Indigenous Chicken Population in South West and South Part of Ethiopia. Brit J Poult Sci 3: 15-19.

15. Hailu A, Mazengia H, Wuletaw Z (2013) Indigenous chicken production system and breeding practice in North Wollo, Amhara region, Ethiopia. Scholarly J Agric Sci 3: 433-444.

16. Melesse A, Worku Z, Teklegiorgis Y (2013) Assessment of the prevailing handling and quality of eggs from scavenging indigenous chickens reared in different agroecological Zones of Ethiopia. J Environ Occup Sci 2:1-8.

17. Mengesha M, Tsega W (2011) Phenotypic and genotypic characteristics of indigenous chickens in Ethiopia: A Review. Afr J Agric Res 6: 5398-5404

18. Faruque S, Siddiquee NU, Afroz MA, Islam MS (2010) Phenotypic characterization of Native Chicken reared under intensive management system. J Bangladesh Agri Univ 8: $79-82$

19. Hassaballah K, Zeuh V, Sembene M (2014) Phenotypic Diversity of Local Chickens (Gallus domesticus) in Three Ecological Zones of Chad. Int J Curr Res Biosc Plant Biol 1: 1-8.

20. Tabassum FMA, Hoque F, Ritchil CH, Faruque MO, Bhuiyan AKFH (2014) Phenotypic and Morphometric characterization of indigenous chickens at jhenaigati upazila of sherpur district in bangladesh. SAARC J Agric 12: 154-169.

21. Liyanage RP, Dematawewal CMB, Silva GLLP (2015) Comparative Study on Morphological and Morphometric Features of Village Chicken in Sri Lanka. Trop Agric Res 26: 261-273.

22. Aklilu E, Kebede K, Dessie T, Banerjee AK (2013) Phenotypic Characterization of Indigenous Chicken Population in Ethiopia. Int J Interdiscip Multidiscip Stud 1: 24-32. 
23. Getu A, Alemayehu K, Wuletaw Z (2014) Phenotypic Characterization of Indigenous Chicken Ecotypes in North Gondar Zone, Ethiopia. Glob Vet 12: 361-368.

24. Melesse A (2007) Poultry Production and Management in the Tropics. Reference teaching book. Hawassa University. $411 \mathrm{pp}$.

25. Reta Duguma (2006) Phenotypic characterization of some indigenous chicken ecotypes of Ethiopia. Livest Res Rural Dev.

26. Dana N, Dessie T, van der Waaij LH, van Arendonk JAM (2010) Morphological features of indigenous chicken populations of Ethiopia. Anim Gen Resources Info 46: 11-23.

27. Renema RA, Robinson FE, Beliveau RM, Davis HC, Lindquist EA (2007) Relationships of body weight, feathering, and footpad condition with reproductive and carcass morphology of end-of-season commercial broiler breeder hens. J Appl Poult Res 16: 27-38

28. Ukwu HO, Okoro VMO, Nosike RJ (2014) Statistical Modelling of Body Weight and Linear Body Measurements in Nigerian Indigenous Chicken. IOSR J Agric Vet Sci 7: 27-30.
29. Goraga Z, Weigend S, Brockmann G (2012) Genetic diversity and population structure of five Ethiopian chicken ecotypes. Anim Genet 43: 454-457. [Crossref]

30. Alabi OJ, Ngambi JW, Norris D, Egen SSA (2012) Comparative study of three indigenous chicken breeds of South Africa: Body weight and linear body measurements. Agric J 7: 220-225.

31. Wimmers K, Ponsuksili S, Hardge T, Valle-Zarate A, Mathur PK, et al. (2000) Genetic distinctness of African, Asian and South American local chickens. Anim Genet 31: 159-165. [Crossref]

32. Pedersen CV (2002) Production of Semi-scavenging chicken in Zimbabwe. $\mathrm{PhD}$ Thesis. Royal Veterinary and Agricultural University, Copenhagen, Denmark. 213Pp.

33. Abdelqader A, Wollny CBA, Gauly M (2008) On-farm investigation of local chicken biodiversity and performance potentials in rural areas of Jordan. Anim. Genetic Resources Info. J. 43: 49-57.

Copyright: (2018 Tadele A. This is an open-access article distributed under the terms of the Creative Commons Attribution License, which permits unrestricted use, distribution, and reproduction in any medium, provided the original author and source are credited. 